\title{
A 2015/2016. tanév országos fittségmérési eredményei a Nemzeti Egységes Tanulói Fittségi Teszt (NETFIT ${ }^{\oplus}$ ) alapján
}

\author{
Results of the Hungarian National Student Fitness Test \\ (NETFIT ${ }^{\circledR}$ ) 2015/2016
}

Szerző: Csányi Tamás $₫$, Kaj Mónika Magyar Diáksport Szövetség

Beküldve: 2017. 12. 08.

doi: 10.24365/ef.v58i4.217

Kulcsszavak: testmozgás; tanulók; fittség

Keywords: physical activity; student; fitness

\section{BEVEZETÉS}

A Nemzeti Egységes Tanulói Fittségi Teszt (NETFIT ${ }^{\circledR}$ ) a magyar köznevelési rendszer kötelező és egységes fittségmérési módszere a 2014/2015. tanévtől kezdődően, amelyet a Magyar Diáksport Szövetség (MDSZ) a Cooper Intézettel közösen fejlesztett ki. A tesztrendszer az egészségközpontú fittségi összetevőket négy profil mentén, hét motoros és két antropometriai értékkel jellemzi. Az alábbi eredmények a 2. tanévi mérés adatain alapulnak, amelyek gyűjtése 2016. január 9. és június 1. között történt. ${ }^{1}$ A mérési időszak teljes kutatási jelentése elérhető az MDSZ honlapján.

\section{MÓDSZEREK}

A NETFIT ${ }^{\circledR}$ egészségközpontú fittségi tesztjei az egyén általános fizikai állapotáról, testösszetételéről, aerob- és vázizomzat fittségéről, valamint hajlékonyságáról nyújtanak információt. A tesztrendszer a következő méréseket tartalmazza: testtömeg- index (BMI), testzsírszázalék-mérés (TZS\%), 20 vagy 15 méteres állóképességi ingafutás teszt (ÁIT), ütemezett hasizom teszt (ÜHT), törzsemelés teszt (TET), kézi szorítóerő mérése (KSZ), ütemezett fekvőtámasz teszt (ÜFT), helyből távolugrás teszt (HTU) és hajlékonysági teszt (HT). A felméréséket az érintett osztályok testnevelést tanító pedagógusa végezte iskolai körülmények között, a testnevelésórák keretein belül. A mérési adatokat a NETFIT ${ }^{\circledR}$ informatikai rendszerébe töltötték fel az Oktatási Hivatal MAZON rendszeréből generált mérési azonosítók segítségével. Összesen 2730 köznevelési intézmény 3802 feladatellátási hellyel tett eleget adatküldési kötelezettségének, amelyből 651431 tanuló (332 230 fiú és 319201 lány) esetében történt meg a mérési eredmény rögzítése is, amely az összes NETFIT ${ }^{\circledR}$ rendszerben lévő diák 88\%-a. A fittségi eredményeket individuális szinten a decimális életkorokat és a nemet figyelembe véve, a sztenderd táblázatok alapján kategorizáltuk: (1) egészségzóna-, (2) fejlesztés szükséges- vagy (3) fokozott fejlesztés szükséges zónába. 


\section{EREDMÉNYEK}

Az egészségzónát elérő tanulók gyakorisága jelentős eltér nemenként, évfolyamonként és tesztenként egyaránt. Összefoglalóan a vizsgált iskolások eredményei

- Testösszetétel és tápláltsági profil:

- $\quad$ BMI 75,3-69,8\% (fiúk); 81,9-72,3\% (lányok);

- TZS\% 73,5-67,6\% (fiúk); 71,6-60,2\% (lányok).

- Aerob fittségi (állóképességi) profil:

- ÁlT 73,7-51,5\% (fiúk); 68,6-33,5\% (lányok).

- Vázizomzat fittségi profil:

- ÜHT 93,3-89,0\% (fiúk); 94,9-89,1\% (lányok);

- TET 56,3-39,0\% (fiúk); 66,0-46,6\% (lányok);

- KSZ 92,9- 70,3\% (fiúk); 98,7-87,6\% (lányok);

- ÜFT 74,1-66,3\% (fiúk); 75,2-67,5\% (lányok)

- $\quad$ HTU 72,2-68,6\% (fiúk); 77,5-73,2\% (lányok).

- Hajlékonysági profil: [77,3-61,7\% (fiúk); 68,1-51,1\% (lányok).

A felső tagozatos és középiskolás összehasonlításban megállapítható, hogy a fiúk esetében kilenc fittségi paraméterből hétben (BMI, TZS\%, ÜHT, TET, $\mathrm{KSZ}, \mathrm{HTU}, \mathrm{HT}$ ), a lányok esetében pedig ötben (BMI, ÜHT, TET, ÜFT, HTU) a középiskolások voltak nagyobb arányban az egészségzónában teljesítők közül.

A regionális és megyei szintú eredmények szerint, a gazdaságilag legfejlettebbnek tekinthető KözépMagyarország Régióban tanuló iskolások tekinthetők a legfittebbeknek.

\section{KÖVETKEZTETÉSEK}

A 2014/2015. tanév során legkritikusabbnak itélt ingafutásban kedvező irányú változás tapasztalható. Összességében a lányok 7 százalékponttal, míg a fiúk 5 százalékponttal nagyobb arányban érték el az egészséghez szükséges minimum fittségi értékeket az előző tanévhez képest. Azonban az életkor növekedésével folyamatosan csökken az egészségzónát elérő tanulók száma. A 12. évfolyamon már csak a fiúk fele, a lányok harmada volt képes az egészségzónában teljesíteni. Ez komoly népegészségügyi kockázatot jelent, hiszen a korábbi tudományos eredményeink szerint a "fokozott fejlesztés” zónában teljesítők mintegy ötször valószínúbb, hogy metabolikus szindrómában szenvednek, mint akik az egészségzónában vannak. ${ }^{2}$ A mindennapos testnevelés szempontjából kulcsfontosságú eredmény, hogy a felmenő rendszeréből először kikerülő évfolyamok (8. és 12.) jelentősen jobban teljesítettek a még nem mindennapos testnevelésben részt vevő évfolyamtársaiknál. Ez nemzetközi szinten is meghatározó eredmény, amely további munkára ösztönözhet. A minden negyedik tanulót érintő túlsúly vagy elhízás újfent megerősíti a népegészségügyi szintű, célzott intervenciók szükségességét. Ezeknek a beavatkozásoknak prioritásként kell kezelniük a rendszeres testmozgás és testedzés népszerúsítését (amelynek elsődleges színtere a mindennapos iskolai testnevelés kell, hogy legyen), továbbá az egészséges és tudatosan szabályozott táplálkozási szokások kialakítását.

Az első mérési eredményekhez hasonlóan KözépMagyarországon és Budapesten a legjobbak a fittségi eredmények, míg Észak-Magyarországon a legkedvezőtlenebbek, amely elsősorban az eltérő regionálisan is kimutatható szociökonómiai jellemzőkkel magyarázható. ${ }^{3}$

Azon tanulók számára, akik elmaradnak az NETFIT ${ }^{\circledR}$ egészségsztenderdjeinek határértékeitől, tervezett fejlesztés, segítségnyújtás szükséges. Osztály-, illetve intézményi szinten pedig, ha nagy a fejlesztési zóná(k)ban teljesítő tanulók száma, célzott, átfogó beavatkozás javasolt. A pedagógus szintjén érdemes átgondolni, hogy mely fittségi profil esetében szükséges hangsúlyosabb fejlesztő hatást elérni az adott tanulócsoport/osztály esetében, összehasonlítani a tanulói adatokat a korábbi eredményekkel. A nemzetközi tapasztalatok alapján a jövőben javasolt egy olyan adatbázis kialakítása, amely a fittségi állapot és a tanulók szocioökonómiai, tanulmányi eredményességi és pszichoszociális háttere közötti összefüggések elemzését teszi lehetővé. 


\title{
HIVATKOZÁSOK
}

\begin{abstract}
${ }^{1}$ Kaj Mónika, Vass Zoltán, Király Anita, Hernádi Ádám és Csányi Tamás (2017). A magyar 10-18 éves tanulók egészségközpontú fizikai fittségi állapota (2016). Kutatási jelentés a Nemzeti Egységes Tanulói Fittségi Teszt (NETFIT ${ }^{\circledR}$ ) 2015/2016. tanévi országos eredményeiről. Magyar Diáksport Szövetség, Budapest.

${ }^{2}$ Laurson, K. R., Saint-Maurice, P. F., Karsai, I., \& Csányi, T. (2015). Cross-validation of FITNESSGRAM ${ }^{\circledR}$ health-related fitness standards in Hungarian youth. Research quarterly for exercise and sport, 86(sup1), S13-S20.

${ }^{3}$ Welk, G. J., Saint-Maurice, P. F., \& Csányi, T. (2015). Health-related physical fitness in Hungarian youth: Age, sex, and regional profiles. Research quarterly for exercise and sport, 86(sup1), S45-S57.
\end{abstract}

